O.R. Gokhman ${ }^{1}$, Yu.A. Asnis ${ }^{2}$, N.V. Piskun ${ }^{2}$, O.A. Velykoivanenko ${ }^{2}$, G.F. Rozynka ${ }^{2}$, A.S. Milenin', V.M. Babych ${ }^{3}$

\title{
Investigation of the Effect of the Electron-Beam Crucible Zone Melting of Metallurgical Silicon on Refining and Structure Formation of Ingots
}

\author{
${ }^{I}$ South Ukrainian National Pedagogical University named after K. D. Ushynsky, 65020-Odesa, Staroprtofrankivsjka 26, \\ Ukraine, e-mail: alex_gokhman@mail.ru \\ ${ }^{2}$ Institute ofElectrowelding named after Ye.O. Paton,NAN of Ukraine, 03680, м. Kuї-150, KazimiraMalevicha, 11, \\ Ukraine,e-mail: asnis@paton.kiev.ua \\ ${ }_{3}^{3}$ Institute of Physics of Semiconductors named after V. Ye. Loshkarev, NAN of Ukraine, 03028, . . Kü̈в-028, Nauka Prospect, 41, \\ Ukraine,e-mail: babich@isp.kiev.ua
}

\begin{abstract}
The paper presents the results of studies obtained with the development of the technology of electron-beam crucible impregnation of metallurgical silicon. It is shown that refining of silicon from background and dopant impurities in electron-beam crucible-free zone melting occurs by zone purification during melting and as a result of evaporation of impurities from the sample surface. The mathematical model and computational experiment were been performed to determine the temperature gradient at different rates of zone melting. It was found the diapason of temperature gradients, which provides the columnar structure of crystallites and the purification of the samplesdue the melting with the zone recrystallization procedure. The level of the resistivity of the ingots increases at the end.
\end{abstract}

Article acted received 07.01.2017; accepted for publication 05.06.2017.

\section{Introduction}

Currently, photoelectric converters (FEC) of solar cells are made of silicon, and experts believe that in the near future there will be no competitive technology based on the use of other materials [1]. Among many ways to produce solar silicon, the production technology, which consists in obtaining solar-grade silicon directly from the metallurgical one, is promising. At the present stage, as one of the trends in the development of silicon production technology for solar energy, direct silicon production has been determined by directional crystallization methods from refined commercial silicon [1]. The criterion for assessing the suitability of metallurgical silicon for its use in the manufacture of FEC is the chemical composition, structure, and electrical parameters..In this work, crucible-free electronbeam zone melting was used to recrystallize metallurgical silicon. In addition to electron beam heating, this method has a number of advantages over other types of melting, namely: during melting it is possible to easily adjust the height of the molten zone; The process can be carried out in a wide temperature range (up to $2200{ }^{\circ} \mathrm{C}$ ). The process efficiency is more than $80 \%$. In the recrystallization of silicon by electronbeam zone melting, the processes of zone purification during melting occur in the crystal being formed, as well as a result of the evaporation of impurities from the surface of the molten zone and heated sections of the sample.

As fundamental in the development of the physics and chemical basis for the production of polycrystals of silicon for FEC [2], during which silicon purification will occur, three basic positions are defined:

1. Low values of the distribution coefficients of most impurities in silicon.

2. Difference in the vapor pressure of different elements at high temperatures.

3 . High vacuum.

The method of crucible-free electron-beam zone recrystallization used in this paper makes it possible to purify silicon determined by these three basic principles. The second and third statements are based on carrying out the process in a high vacuum and the difference in the vapor pressure of the various elements, which will lead to the removal of components for which 
the vapor pressure is higher than the elasticity of silicon vapor. In Fig. 1 presents data on the dependence of the pressure of saturated vapor of elements on temperature [1]. From the analysis of these data, it can be concluded that evaporation from the surface of a sample of $\mathrm{K}, \mathrm{N}$, $\mathrm{Ca}, \mathrm{Ba}, \mathrm{As}$, and $\mathrm{P}$ can be expected from the melt. It should be noted that for elements such as phosphorus, arsenic and oxygen due to the high value of equilibrium. Distribution coefficients zone cleaning is ineffective, therefore, their purification will go, mainly, due to evaporation.In this paper, an ingot of polycrystalline silicon, obtained by induction melting in a cold crucible, was used for research.Specific electrical resistance of the starting material: $0.9 \mathrm{Ohm} \cdot \mathrm{cm}$.

The chemical composition of the ingot, presented in Table.1 was determined on a GDMS glow discharge mass spectrometer. The conductivity type is n-type.

Specific electrical resistance is one of the most important parameters determining the quality of semiconductor silicon. This parameter characterizes the degree of purity of semiconductor materials [3].The cyclograms of the process of electron-beam crucible-free zone melting of metallurgical silicon were developed. Melting of the samples was carried out at velocities of $0.0056 \mathrm{~mm} / \mathrm{s} ; 0.014 \mathrm{~mm} / \mathrm{s} ; 0.028 \mathrm{~mm} / \mathrm{s} ; 0.039 \mathrm{~mm} / \mathrm{s}$; $0.056 \mathrm{~mm} / \mathrm{s} . I n$ Fig. 2 shows the cyclograms of the electron-beam crucible zone melting process of silicon polycrystals for melting rates of $0.0056-0.056 \mathrm{~mm} / \mathrm{s}$.

As can be seen from the cyclograms, the anode current changes little during the entire melting cycle. Some of its decrease towards the end of the melting is due to the general heating of the sample during the melting process, as well as the heating of the reinforcement in the growth chamber.According to the developed cyclograms, zone melting of metallurgical silicon was carried out. In Fig. 3 shows a sample of

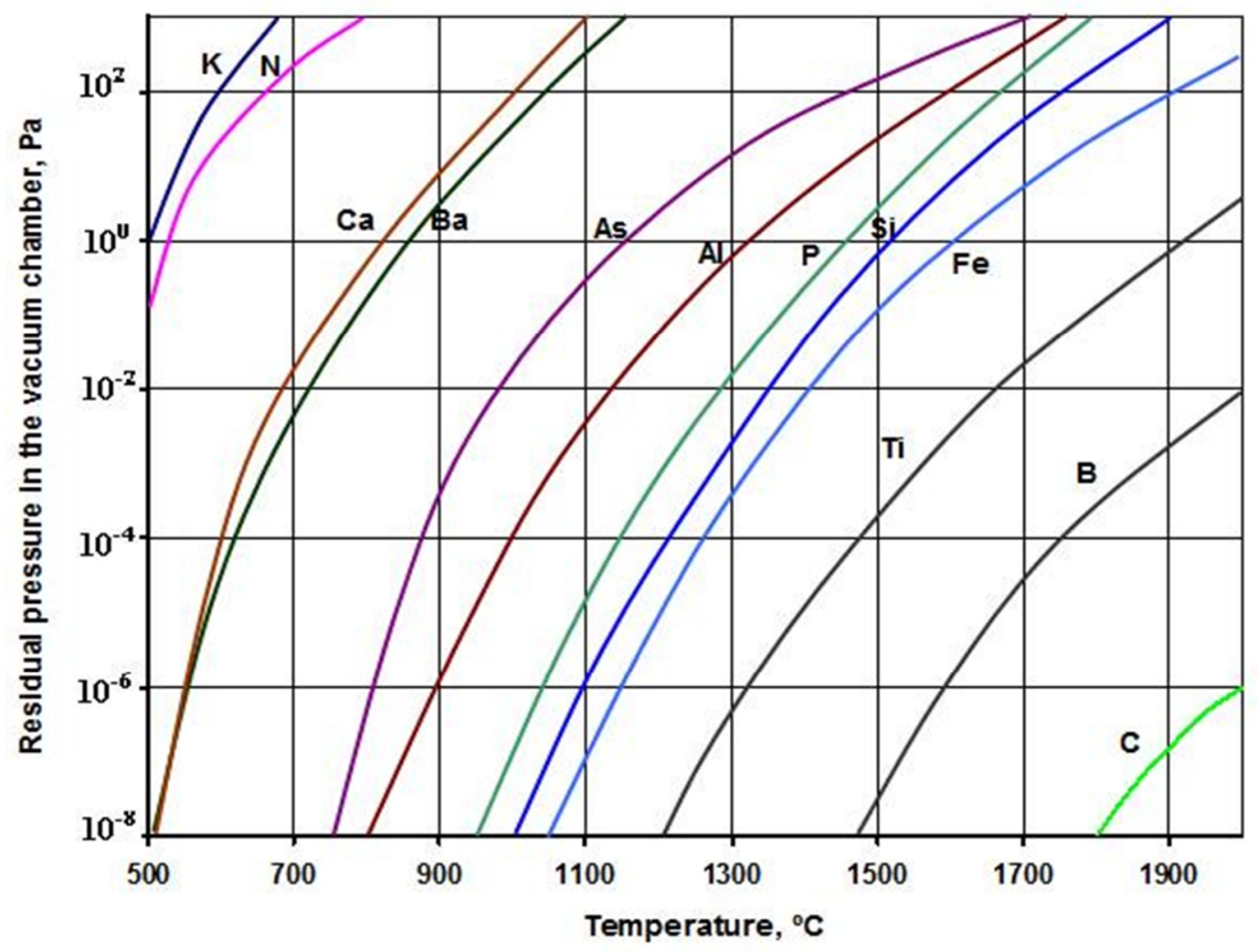

Fig.1. Dependence of vapor pressure of various elements - impurities on temperature [1].

Table 1

Chemical composition of the ingot

\begin{tabular}{|c|c|c|c|c|c|c|c|c|}
\hline № & Element & $\begin{array}{c}\text { Concentration } \\
\text { ppma }\end{array}$ & № & Element & $\begin{array}{c}\text { Concentration } \\
\text { ppma }\end{array}$ & № & Element & $\begin{array}{c}\text { Concentration, } \\
\text { ppma }\end{array}$ \\
\hline 1 & $\mathrm{~B}$ & 0.434 & 10 & $\mathrm{Ti}$ & 0.021 & 19 & $\mathrm{Cd}$ & 0.000 \\
\hline 2 & $\mathrm{Na}$ & 0.357 & 11 & $\mathrm{~V}$ & 0.014 & 20 & $\mathrm{In}$ & 0.000 \\
\hline 3 & $\mathrm{Mg}$ & 0.115 & 12 & $\mathrm{Cr}$ & 0.345 & 21 & $\mathrm{Sn}$ & 0.093 \\
\hline 4 & $\mathrm{Al}$ & 0.247 & 13 & $\mathrm{Mn}$ & 0.089 & 22 & $\mathrm{Ag}$ & 0.584 \\
\hline 5 & $\mathrm{P}$ & 0.797 & 14 & $\mathrm{Fe}$ & 2.480 & 23 & $\mathrm{Ba}$ & 0.057 \\
\hline 6 & $\mathrm{Ga}$ & 0.000 & 15 & $\mathrm{Co}$ & 0.040 & 24 & $\mathrm{~W}$ & 0.036 \\
\hline 7 & $\mathrm{~K}$ & 0.299 & 16 & $\mathrm{Ni}$ & 0.180 & 25 & $\mathrm{Ag}$ & 0.584 \\
\hline 8 & $\mathrm{Ca}$ & 4.414 & 17 & $\mathrm{Zn}$ & 1.714 & 26 & $\mathrm{Au}$ & 0.000 \\
\hline 9 & $\mathrm{Sc}$ & 0.003 & 18 & $\mathrm{As}$ & 0.100 & 27 & $\mathrm{Bi}$ & 0.003 \\
\hline
\end{tabular}




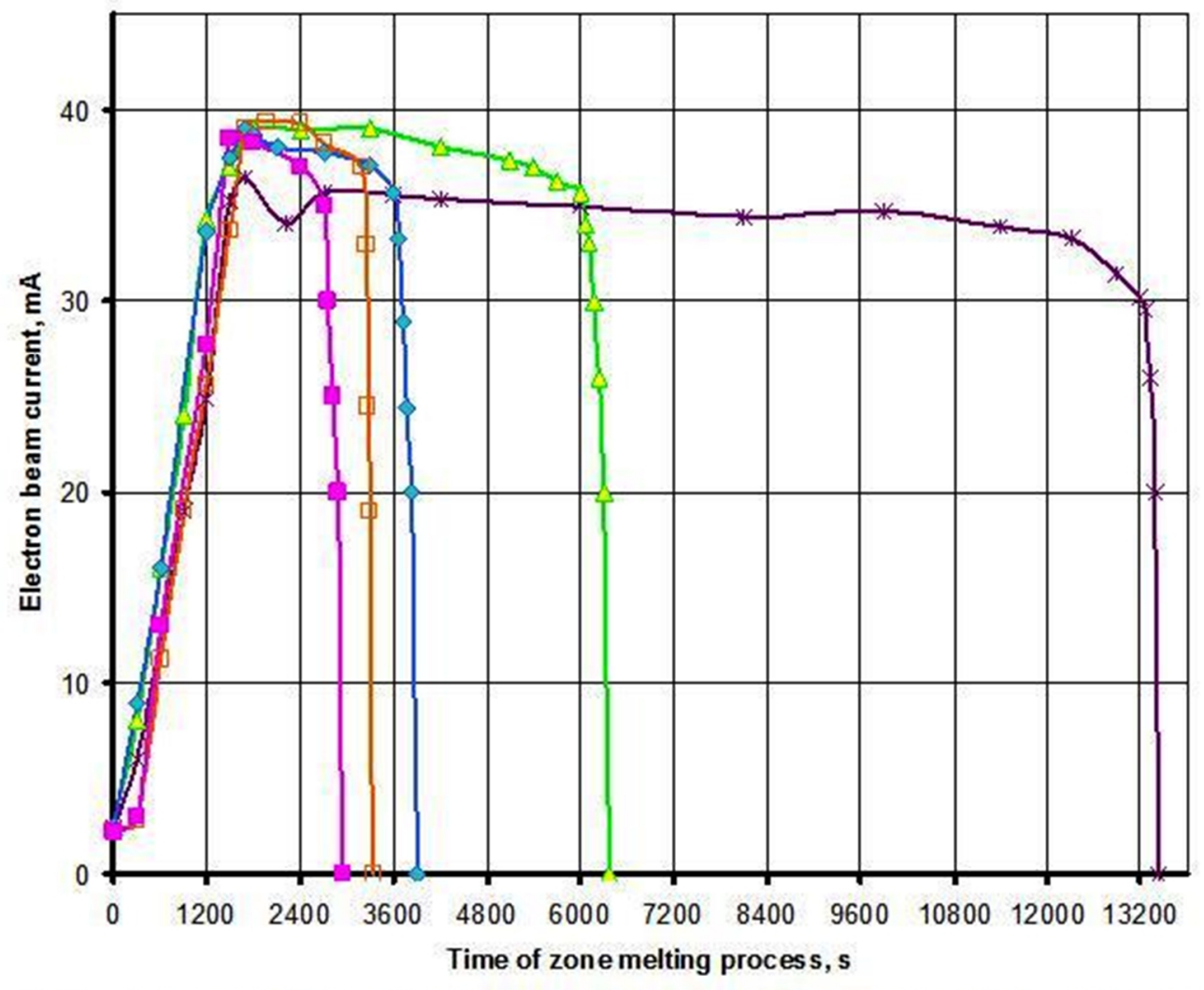

Fig. 2. Cyclograms of the process of electron-beam zone melting of polycrystals of silicon.

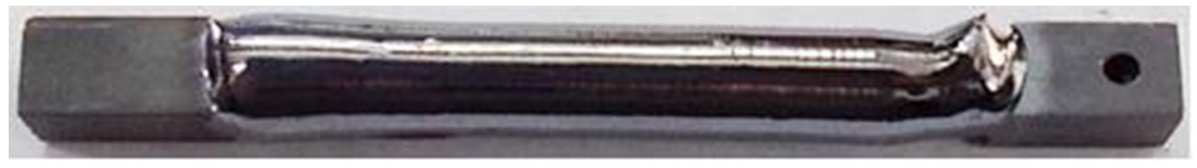

Fig. 3. Polycrystalline silicon after zone melting.

silicon after zone recrystallization.

Calculation methods have been established and experimentally confirmed with the example of oxygen and phosphorus, that refining silicon during melting should be carried out at recrystallization rates not lower than $0.014 \mathrm{~mm} / \mathrm{s}$. Remelting at a speed lower than $0.014 \mathrm{~mm} / \mathrm{s}$ is ineffective. It was shown that the decrease in the mass content of oxygen and phosphorus during melting is achieved due to the presence of a welldeveloped free surface of the molten zone and is determined by the processes of evaporation and degassing into vacuum. [4]

The chemical composition of the silicon ingot after zone recrystallization in was determined using a GDMS mass spectrometer. The data are presented in Table. 2.

As can be seen from the table, the impurities are cleared, caused by the joint action - zone melting and degassing into vacuum. It is known $[5,6]$ that the electrophysical parameters of silicon largely depend not only on the purity of silicon, but also on the structure of the crystallites, their location, dimensions, and the number of grain boundaries (NGB). Therefore, in addition to purification of silicon from impurities, special attention must be given to the structure of the grown ingot, forming it with directional crystallization with the formation of a columnar structure with a minimum amount of NGB. In order to grow the ingot, it is necessary to provide such crystallization parameters in order to obtain an ingot in accordance with the requirements listed above. The columnar structure of the ingot is formed at certain speeds. This is due to the different values of the temperature gradient arising at the boundary between the liquid and solid phases [7]. As was mentioned above [8], the following factors affect the value of the temperature gradients of a liquid-solid phase: thermophysical properties of the material; rate of crystallization; latent heat of crystallization; thermal convection that develops during melting. To determine the temperature gradient at the boundary of the liquid and solid phases at different rates of crystallization (in our case, the rate of crystallization is equal to the speed of motion of the heater forming the molten zone) and to determine its effect on the structure and resistivity, a mathematical model has been developed that takes into account the factors listed above and carried out the computational experiment. In the development of the mathematical model, it was assumed that in a sample of length $L$, the constant height of the molten zone is 
The chemical composition of ingots of polycrystalline silicon after recrystallization zone

Table 2 at a speed of $0.028 \mathrm{~mm} / \mathrm{sec}$

\begin{tabular}{|c|c|c|c|c|c|c|c|c|}
\hline № & Element & $\begin{array}{c}\text { Concentration } \\
\text { ppma }\end{array}$ & № & Element & $\begin{array}{c}\text { Concentration } \\
\text { ppma }\end{array}$ & № & Element & $\begin{array}{c}\text { Concentration, } \\
\text { ppma }\end{array}$ \\
\hline 1 & $\mathrm{~B}$ & 0.492 & 10 & $\mathrm{Ti}$ & 0.010 & 19 & $\mathrm{Cd}$ & 0.000 \\
\hline 2 & $\mathrm{Na}$ & 0.250 & 11 & $\mathrm{~V}$ & 0.001 & 20 & $\mathrm{In}$ & 0.000 \\
\hline 3 & $\mathrm{Mg}$ & 0.082 & 12 & $\mathrm{Cr}$ & 0.0265 & 21 & $\mathrm{Sn}$ & 0.044 \\
\hline 4 & $\mathrm{Al}$ & 0.113 & 13 & $\mathrm{Mn}$ & 0.031 & 22 & $\mathrm{Ag}$ & 0.328 \\
\hline 5 & $\mathrm{P}$ & 0.226 & 14 & $\mathrm{Fe}$ & 0.874 & 23 & $\mathrm{Ba}$ & 0.001 \\
\hline 6 & $\mathrm{Ga}$ & 0.000 & 15 & $\mathrm{Co}$ & 0.008 & 24 & $\mathrm{~W}$ & 0.012 \\
\hline 7 & $\mathrm{~K}$ & 0.085 & 16 & $\mathrm{Ni}$ & 0.018 & 25 & $\mathrm{Pt}$ & 0.000 \\
\hline 8 & $\mathrm{Ca}$ & 0.508 & 17 & $\mathrm{Zr}$ & 1.341 & 26 & $\mathrm{Au}$ & 0.000 \\
\hline 9 & $\mathrm{Sc}$ & 0.002 & 18 & $\mathrm{As}$ & 0.002 & 27 & $\mathrm{Bi}$ & 0.002 \\
\hline
\end{tabular}

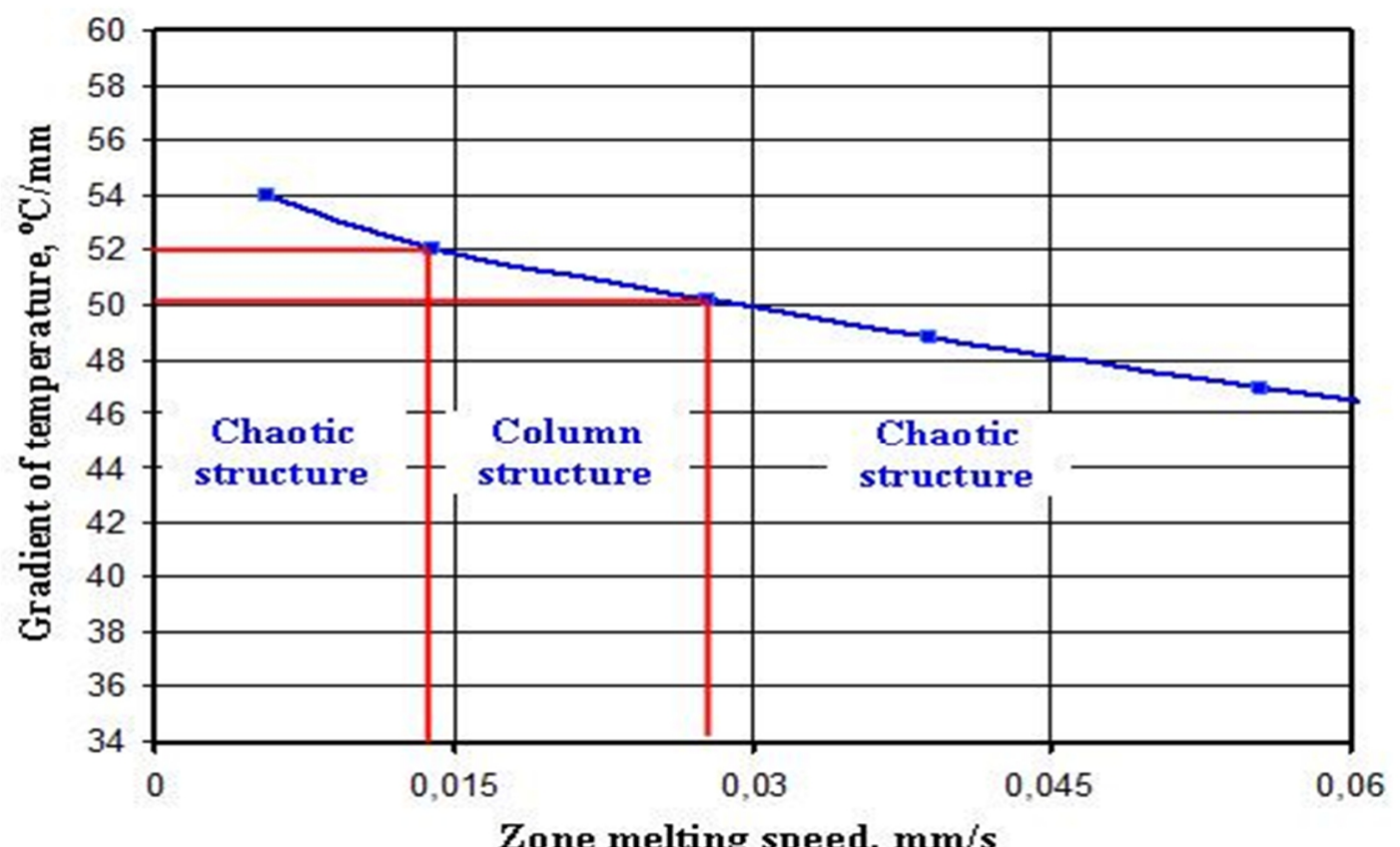

Fig. 4. Dependence of the temperature gradient on the rate of crystallization.

maintained, the rate of displacement of the crystallization front is equal to the melting rate of the sample, convective mixing in the liquid zone is quite intense.

The 2-dimensional heat conduction problem in a cylindrical coordinate system was solved. With boundary conditions on the upper and lower surfaces:

$$
\frac{\partial}{\partial r}\left(\lambda \frac{\partial T}{\partial r}\right)+\frac{\partial}{\partial z}\left(\lambda \frac{\partial T}{\partial z}\right)=c \gamma \frac{\partial T}{\partial t},
$$

with boundary conditions on the upper and lower surfaces

$$
\lambda \frac{\partial T}{\partial z}=-\alpha_{T}\left(T-T_{c m}\right),
$$

and on the lateral surface

$$
\lambda \frac{\partial T}{\partial r}=Q+q h,
$$

where - radiant heat exchange, $\mathrm{W} / \mathrm{m}^{2}: \mathrm{Q}=\sigma \cdot \varepsilon \cdot[(\mathrm{T}+$ $\left.273)^{4}-\left(T_{\mathrm{W}}+273\right)^{4}\right]$; $\sigma$ is the Stefan-Boltzmann constant, equal to $5.67 \cdot 10^{-8} \mathrm{~W} / \mathrm{m}^{2} \cdot \mathrm{K}^{4} ; \varepsilon$ is the degree of blackness equal to $0.5 ; T$ - sample temperature, ${ }^{\circ} \mathrm{C} ; T_{\mathrm{W}}$ is the temperature of the walls of the vacuum chamber, ${ }^{\circ} \mathrm{C}$; $\lambda$ is thermal conductivity coefficient, $\mathrm{W} / \mathrm{m} \cdot{ }^{\circ} \mathrm{C} ; h$ is the efficiency function of the source, which in the zone of the electron beam heater $(\mathrm{EBH})$ takes the value $h=1$, while outside the EBH zone $h=0 ; \alpha_{\mathrm{T}}$ is the coefficient of surface heat transfer, $\mathrm{W} / \mathrm{m}^{2} \cdot{ }^{\circ} \mathrm{C} ; c_{\gamma}$ is the volumetric heat capacity, $\mathrm{J} / \mathrm{m}^{3} \cdot{ }^{\circ} \mathrm{C}$; - power input $\mathrm{EBH}, \mathrm{W} / \mathrm{m}^{2}$.

In the calculations, the cyclograms of the electronbeam zone melting process, shown in Fig. 2.For different melting rates, the temperature gradient along the crystallization front was determined. In Fig. 4 shows the dependence of the temperature gradient on the boundary between the liquid and solid phases on the melting rate. As can be seen from the figure, with an increase in the melting rate, the temperature gradient at the boundary between the liquid and solid phases decreases.

Calculations showed that at crystallization rates of 0.014 and $0.028 \mathrm{~mm} / \mathrm{s}$, a uniform distribution of the temperature gradient over the ingot section was obtained. At a velocity less than $0.014 \mathrm{~mm} / \mathrm{s}$ (Fig. 5, a), the gradient over the section is inhomogeneous. As shown by the structural studies given below, this contributes to the 


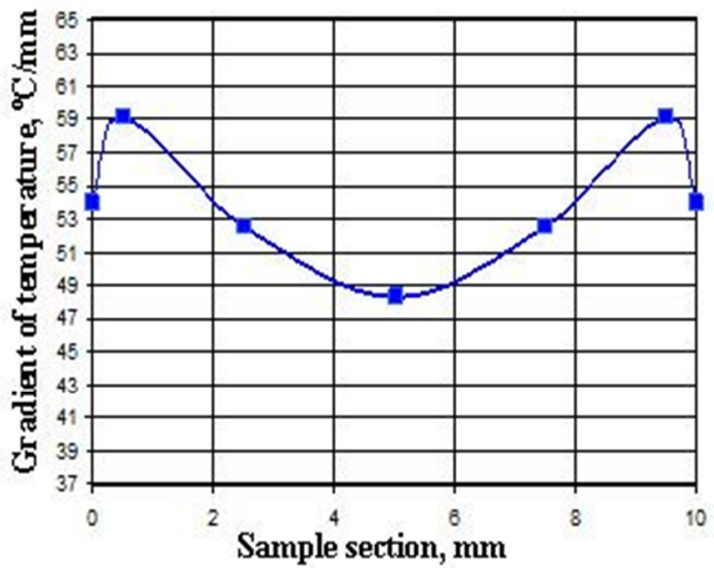

a

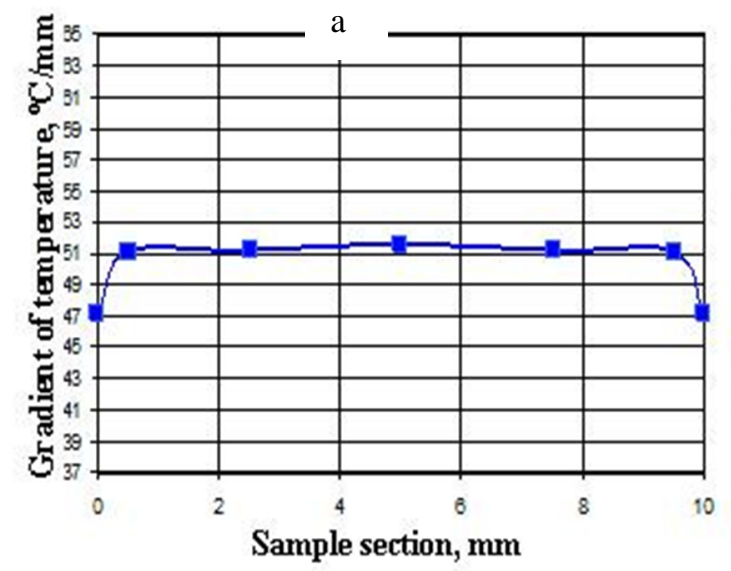

B

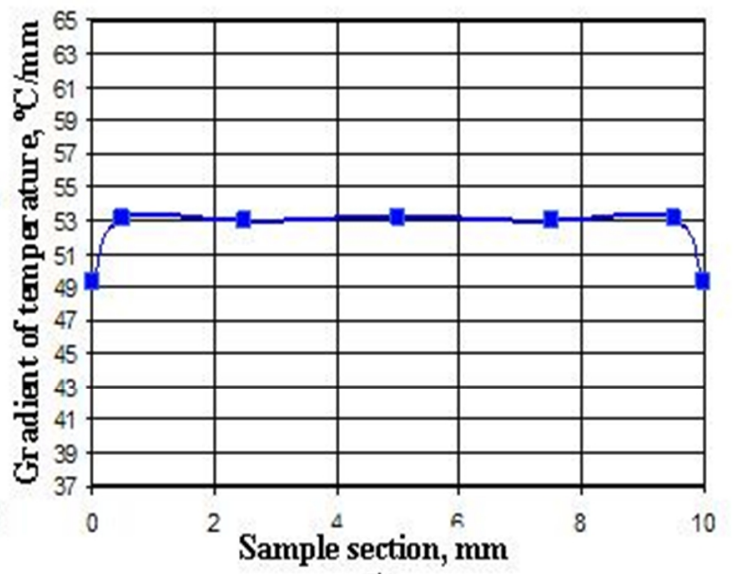

6

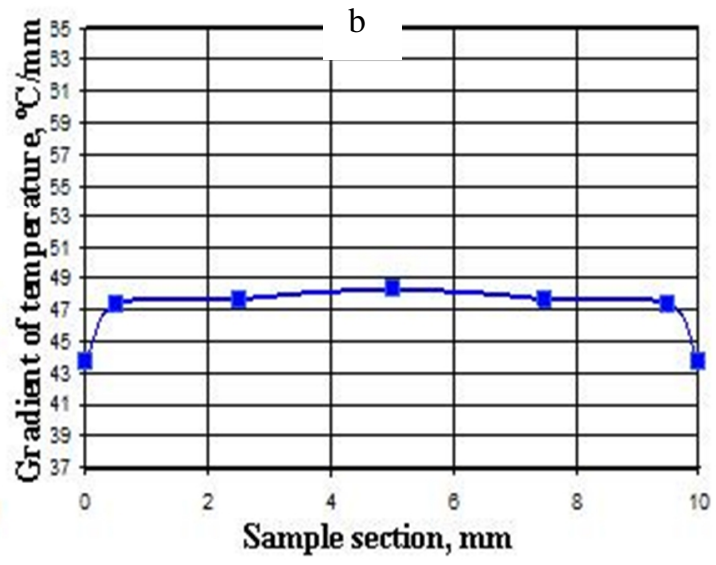

$\Gamma$

Fig. 5. Distribution of the te $c$ ure gradient over the cross section of the san, ${ }^{d}, \mathrm{l}$ the middle of the ingot for different rates of zone melting: a) $0.0056 \mathrm{~mm} / \mathrm{s}$; b) $0.014 \mathrm{~mm} / \mathrm{s}$; c) $0.028 \mathrm{~mm} / \mathrm{s}$; d) $0.056 \mathrm{~mm} / \mathrm{s}$.

disruption of the formation of the columnar structure the appearance of crystallites growing in other directions. At velocities above $0.028 \mathrm{~mm} / \mathrm{s}(5 \mathrm{~d})$, the temperature gradient over the section is distributed relatively uniformly, but its value is lower than $0.028 \mathrm{~mm} / \mathrm{s}$, which in turn also contributes to the violation of the columnar structure. As was mentioned above, according to the data of $[4,8]$, the electrophysical properties in the entire volume of polycrystalline silicon intended for solar batteries are structurally sensitive, i.e. depend on the location of the crystallites, their dimensions and the characteristics of the grain boundaries. Metallographic investigations of silicon ingots in the initial state and after zone recrystallization were carried out. To determine the macrostructure, etching was carried out in $10 \%$ boiling $\mathrm{KOH}$ solution for $4-6$ minutes. Studies of the macrostructure of the initial polycrystalline material showed (Fig. 6) that the crystals in the ingot are located randomly.

In ingots produced at speeds of $0.0056 \mathrm{~mm} / \mathrm{s}$, the randomness in the arrangement of grains is observed, as in the main material. In addition, the deviation from the directed crystal growth along the vertical axis of the sample is seen. When melting at a speed of $0.014 \mathrm{~mm} / \mathrm{s}$, a columnar structure is mainly formed. The structure of the samples after zone recrystallization at a rate of $0.028 \mathrm{~mm} / \mathrm{s}$ (Fig. 7, d) is characterized by even columns

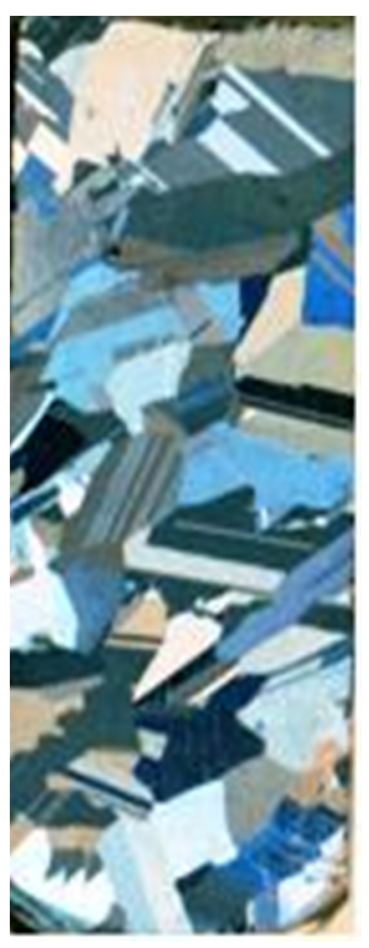

Fig. 6. Macrostructure polycrystalline silicon band recrystallization $\mathrm{X} 5$. 


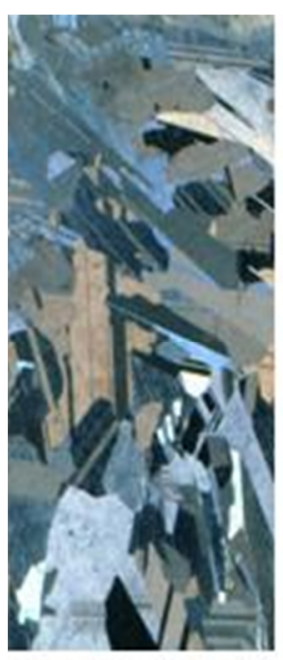

a

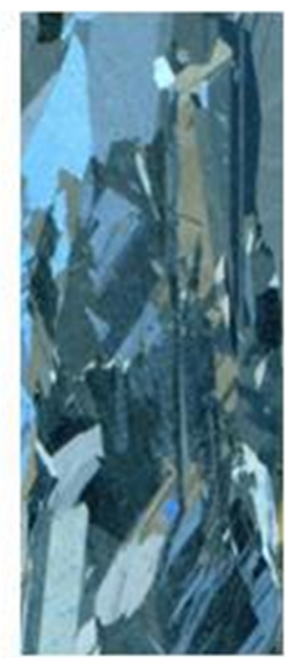

b

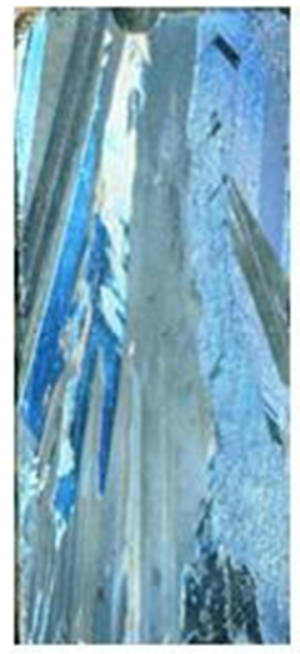

c

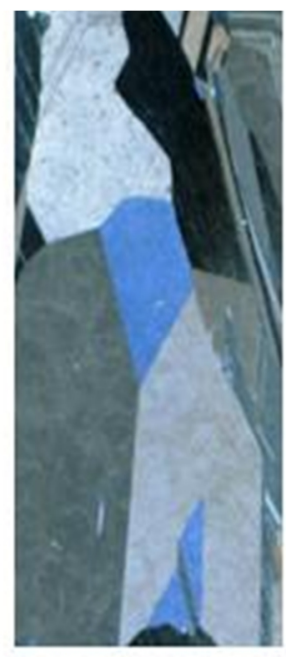

d

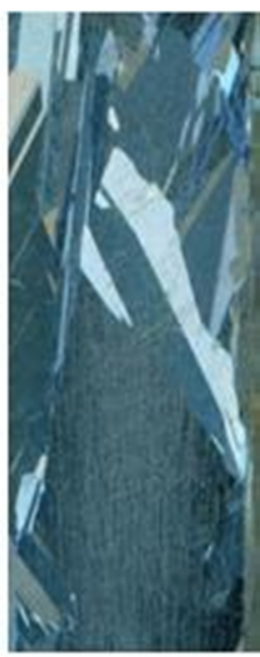

e

Fig. 7. Sample macrostructure silicon band after recrystallization obtained by melting speeds: a) - $0.0056 \mathrm{~mm} / \mathrm{s}$; $\mathrm{b}-0.014 \mathrm{~mm} / \mathrm{s} ; \mathrm{c}-0.028 \mathrm{~mm} / \mathrm{s} ; \mathrm{d}-0.039 \mathrm{~mm} / \mathrm{s} ; \mathrm{e}-0.056 \mathrm{~mm} / \mathrm{s}$.

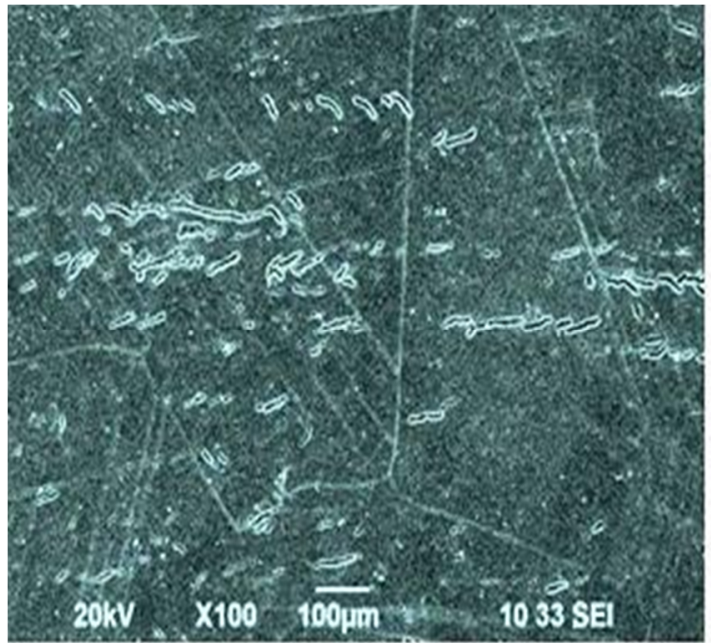

a

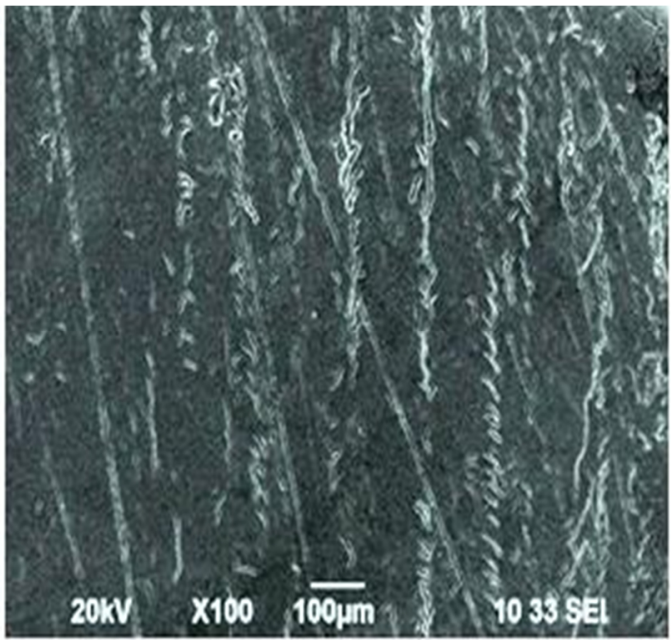

b

Fig. 8. Microstructure of samples of polycrystalline silicon in the initial state and after zone recrystallization.

of large-sized crystallites with uncorrelated boundaries. Their arrangement is vertical along the crystallization front line. On samples obtained at speeds of $0.039 \mathrm{~mm} / \mathrm{s}$; and $0.056 \mathrm{~mm} / \mathrm{s}$ (Fig. 7, d, e), solid crystals with continuous boundaries located in different directions are observed. Studies have shown that the sizes of crystallites vary from 0.3 to $0.8 \mathrm{~cm}$ for all the investigated rates of recrystallization. Thus, as a result of investigations, it was established that the optimum ingot structure meeting the requirements of solar silicon is formed at recrystallization rates from 0.014 to $0.028 \mathrm{~mm} / \mathrm{s}$.

Macrostructure polycrystalline silicon samples obtained at different speeds melting shown in Fig. 7 (a, b, c, d, e).

On the electronic scanning microscope JOEL, microstructure studies of silicon samples in the initial state and after electron-beam zone melting were carried out. Chemical etching was used to detect the microstructure. The solution consists of nitric, acetic and hydrofluoric acids in the ratio: 5h. HNO3+ 3 h. $\mathrm{CH} 3 \mathrm{COOH}+3 \mathrm{~h}$. HF. The results of investigations of the microstructure are shown in Fig. 8 (a, b). As can be seen from Fig. 8a, in the structure of a sample of polycrystalline silicon before remelting, the grain boundaries are closed straight lines. There are also areas of grains with etch pits, located mainly in small chains, intersecting grain boundaries, and in some places located chaotically. In Fig. $8 \mathrm{~b}$ shows the microstructure of silicon after zone recrystallization. Straight grain boundaries are visible parallel to each other. The pits of etching after remelting are aligned by straight chains along the direction of the boundaries, which positively affects the electrophysical characteristics of silicon.

Figure 9 shows the distribution of the electrical resistivity along the length of the silicon ingot at different rates of zone melting.

As can be seen, the highest values of the resistivity $1.3 \ldots 1.4 \mathrm{Ohm} \cdot \mathrm{cmare}$ observed at melting rates from 0.014 to $0.028 \mathrm{~mm} / \mathrm{s}$.

As indicated above, metallographic studies have shown that the directional columnar structure is observed in the range of crystallization rates from 0.014 to $0.028 \mathrm{~mm} / \mathrm{s}$, which corresponds to a temperature gradient 


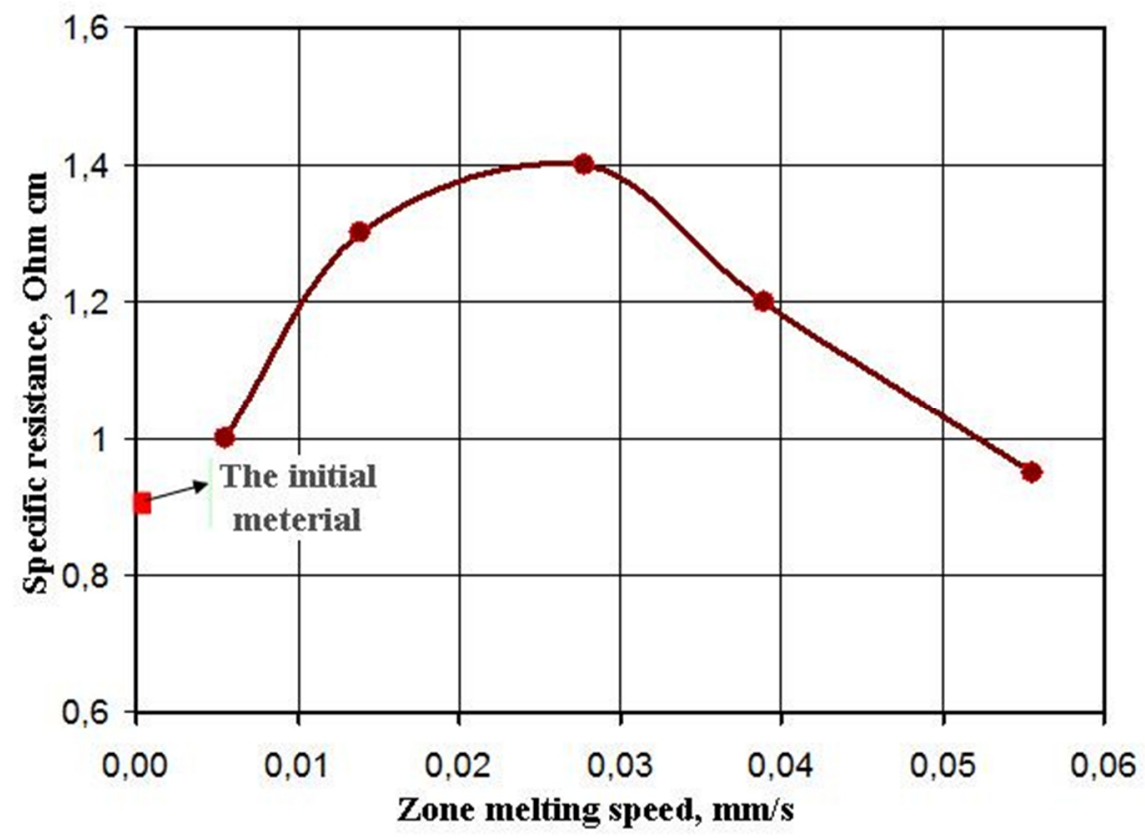

Fig. 9. Dependence of the specific electrical resistivity on the melting rate of samples of metallurgical silicon.

at the boundary of the liquid and solid phases of 50 $52 \mathrm{deg} / \mathrm{mm}$. This fact (Fig. 9) and the zone purification during melting and evaporation of impurities from the surface of the sample provide the highest level of the resistivity.

\section{Conclusions}

1. It is shown that in the electron-beam crucible zone melting of metallurgical silicon, purification is carried out by distillation of impurities and evaporation of impurities from the sample surface in a vacuum.

2. A mathematical model was developed and a computational experiment was performed to determine the temperature gradient at the boundary of the liquid solid phase at different rates of zone melting.

3. It has been established that directional crystallization with a columnar structure and rectilinear intergranular boundaries during the recrystallization of metallurgical silicon depends on the ratio of the rates of zone melting and the temperature gradient at the boundary of the liquid and solid phases and is formed at a temperature gradient from 50 to $52 \mathrm{deg} / \mathrm{mm}$.

4. The highest indices of the electrical resistivity and the uniformity of its distribution in the volume of the ingot are observed during the recrystallization of polycrystalline silicon at speeds from 0.014 to $0.028 \mathrm{~mm} / \mathrm{s}$.

Gokhman O.R. - Professor, Dr. of Phys. and Math. Sci., Head of Department of Physics;

Asnis Yu.A. - Dr. of Technical Sci., Senior Researcher, Head of Department;

Piskun N.V. - Ph.D (Technical Sci.), Senior Researcher; Statkevich I.I. - Researcher;

Velykoivanenko O.A. - PH.D (Technical Sci., Senior Research, Senior Research Fellow;

Rozynka G.F. - Researcher;

Milenin O.C. - Ph.D (Technical Sci.), Senior Researcher;

Babich V.M. - Professor, Dr. of Phys. and Math. Sci.

[1] A.I. Nepomnyaschih, V.P. Eremin, B.A. Krasin i dr., Materialyi elektronnoy tehniki (4), 16, (2002)

[2] A.I. Nepomnyaschih, B.A. Krasin, V.S. Romanov i dr. Pat. RF № 2131843 Byul. M17 ot 20.06.99.

[3] S.A. Garyainov, Yu.S. Tihodeev, Fizicheskie modeli poluprovodnikovyih priborov s otritsatelnyim soprotivleniem (Radio i svyaz, Moskva, 1997).

[4] E.A. Asnis, A.B. Lesnoy, N.V. Piskun, Sovremennaya elektrometallurgiya (3), 11 (2011).

[5] N.I. Kazakova, N.V. Nemchinova, B.A. Krasin, Sovremennyie problemyi nauki i obrazovaniya, 6(3), 158, (2007).

[6] B.A. Krasin, A.I. Nepomnyaschih, A.S. Tokarev i dr., Materialyi elektronnoy tehniki (1), 28, (2005).

[7] V.P. Ginkin, S.M. Ganina K.P. Chernov, Matematicheskoe modelirovanie fizicheskih protsessov (4), 58 (2013).

[8] S.S. Belskiy, N.V. Nemchinova, B.A. Krasin, Sovremennyie naukoemkie tehnologii (4), 26, (2006). 


\title{
О.Р. Гохман ${ }^{1}$, Ю.А. Асніс ${ }^{2}$, Н.В. Піскун ${ }^{2}$, І.І. Статкевич ${ }^{2}$, О.А. Великоіваненко ${ }^{2}$, Г.Ф. Розинка 2 О.С. Міленін ${ }^{2}$, В.М. Бабич ${ }^{3}$ \\ Дослідження впливу режимів електронно-променевої безтигельної зонної плавки металургійного кремнію на рафінування та структуроутворення зливків
}

\author{
${ }^{1}$ Південноукраӥнський начіональний педагогічний університет ім. К. Д. Уиинського», 65020, м. Одеса, \\ вул. Старопортофранківська, 26, e-mail: alex_gokhman@таil.ru \\ ${ }^{2}$ Інститут електрозварювання ім. С.О. Патона НАНУ, 03680, м. Кийв-150, \\ вул. Казимира Малевича, 11, e-mail: asnis@paton.kiev.ua \\ ${ }^{3}$ Iнститут фізики напівпровідників ім. В.С. Лашкарьова НАНУ, 03028, м. Київ-028, Проспект Науки, 41, \\ e-mail: babich@isp.kiev.ua
}

\begin{abstract}
У роботі представлені результати досліджень, які отримані при розробці технології електроннопроменевої безтигельної зонної плавки металургійного кремнію. Показано, що рафінування кремнію від фонових і легуючих домішок при електронно-променевій безтигельній зонній плавці відбувається шляхом зонного очищення при плавці і в результаті випаровування домішок з поверхні зразка. Створено математичну модель i проведено обчислювальний експеримент, за допомогою якого визначено температурний градієнт при різних швидкостях зонного плавлення. Встановлено межі температурних градієнтів, при яких в процесі плавки формується стовпчаста структура кристалітів, що забезпечує разом з очищенням зразків в результаті зонної перекристалізації підвищення рівня питомого електроопору зливків.

Ключові слова: полікристалічний кремній, фотоелектричні перетворювачі, електронно-променева безтигельна зонна плавка, рафінування, спрямована кристалізація, стовбчата структура, питомий електроопір.
\end{abstract}

